\title{
SISTEM PENDUKUNG KEPUTUSAN PELANGGAN TERBAIK DAN PEMBERIAN DISKON MENGGUNAKAN METODE SAW \& TOPSIS
}

\author{
Taufik Kurnialensya ${ }^{1}$, Rohmad Abidin ${ }^{2}$ \\ ${ }^{1}$ Teknik Informatika - Sekolah Tinggi Elektronika dan Komputer (STEKOM),taufik@stekom.ac.id \\ ${ }^{2}$ Komputerisasi Akuntansi - Sekolah Tinggi Elektronika dan Komputer \\ (STEKOM),rohmad@stekom.ac.id
}

Jl. Majapahit 605, Semarang, telp/fax : 024-6717201-02

\section{ARTICLE INFO}

Article history:

Received 1 Mei 2020

Received in revised form 22 Mei 2020

Accepted 30 Mei 2020

Available online 9 Juni 2020

\section{ABSTRACT}

Decision Support System is an interactive information system that provides information, modeling and manipulation of data. The system is used to assist decision making in semi-structured situations and unstructured situations. As a result of the company's annual targets are still difficult to achieve, it is also feared if consumers move to other companies that may have similar products at lower prices. Therefore, promotion strategies must be updated in the form of discounts or special discounts for consumers with the most total purchases in a year. Based on the existing problems, an annual customer decision support information system program is created and discounts are given through recapitulation of total consumer purchases within a year. For the calculation method itself uses the SAW Method as a supporter of the best customer selection decision and TOPSIS as a supporter of the decision to give a discount. From the results of the research produced: using the PHP programming language can be used to help companies to choose the best customer and determine the discount validly, the application has been made can be used as a tool for decision makers by remaining based on a more effective decision support system in selecting the best customers and determining discounts using the SAW (Simple Additive Weighting) and Topsis (Technique for Order Preference by Similarity to Ideal Solution) methods. Keywords: SPK, SAW, TOPSIS

Keywords: DSS, TOPSIS, SAW.

\section{Pendahuluan}

Di era globalisasi seperti sekarang ini, semua dituntut berjalan serba cepat.Dunia teknologi informasi berkembang dengan cepat terpacu oleh dunia persaingan yang begitu ketat. Komputer yang tadinya digunakan sebagai pengganti mesin ketik, sekarang dituntut untuk menjadi sarana pendukung berjalannya kegiatan bisnis proses perusahaan. Sistem informasi dan teknologi informasi dirancang untuk meningkatkan kinerja perusahaan.Dalam sebuah binis, teknologi informasi juga memiliki peran penting. Terlebih dalam mengembangkan pemasaran produk.

Pemasaran merupakan salah satu kegiatan paling penting yang dilakukan oleh para pengusaha dalam usahanya mempertahankan kelangsungan hidup, berkembang, kemampuan untuk bersaing serta 
mendapatkan laba.Tidak ada satu perusahaan yang mampu bertahan bilamana perusahaan tersebut tidak mampu memasarkan atau menjual barang-barang yang dijualnya.

Salah satu faktor terpenting dalam pemasaran adalah dengan menyusun strategi pemasaran yang konsisten dengan tujuan pemasaran yang salah satunya adalah dengan melakukan program pemilihan pelanggan terbaik yang tujuannya untuk meningkatkan daya beli konsumen terhadap produk yang dipasarkan.Penghargaan yang diberikan kepada pelanggan terbaik bisa berupa pemberian harga kusus atau diskon. Hal tersebut akan membuat pelanggan sulit untuk mengalihkan pandangannya ke perusahaan lain yang sama-sama memasarkan produk yang sama, tentunya selain itu perusahaan juga harus menjaga kualitas produk yang mereka pasarkan.

Smartkids Distributor yang beralamat di Jl. Imam Bonjol 163 Semarang merupakan salah satu dealer cabang dari PT. Mentari Books Indonesia yang berdiri sejak 1 Maret 2007. Sarana promosi yang sudah dilakukan oleh Smartkids meliputi menyebar brosur ke sekolah-sekolah, menempel stiker nomor telphon dan alamat email pada setiap buku yang di display juga membuka bazar di acara open house yang diadakan sekolah-sekolah tiap tahunnya. Bagi Smartkids Distributor Semarang, bukan hal yang mudah untuk menentukan pelanggan terbaik. Salah satu kendala yang harus dihadapi adalah komponen penilaian atau kriteria penilaian dan metode yang jelas dalam penialaian terhadap pelanggan.

Tabel 1: Hasil penjualan perbulan

\begin{tabular}{llclr}
\hline No & Bulan & Jumlah Pelanggan & \multicolumn{2}{c}{ Total Transaksi } \\
\hline 1 & Januari & 83 & $\mathrm{Rp}$ & $13,836,850$ \\
2 & Februari & 42 & $\mathrm{Rp}$ & $10,505,735$ \\
3 & Maret & 43 & $\mathrm{Rp}$ & $29,912,000$ \\
4 & April & 34 & $\mathrm{Rp}$ & $9,244,500$ \\
5 & Mei & 34 & $\mathrm{Rp}$ & $104,920,100$ \\
6 & Juni & 59 & $\mathrm{Rp}$ & $134,082,100$ \\
7 & Juli & 95 & $\mathrm{Rp}$ & $41,220,340$ \\
8 & Agustus & 137 & $\mathrm{Rp}$ & $47,548,960$ \\
9 & Spertember & 70 & $\mathrm{Rp}$ & $27,567,750$ \\
10 & Oktober & 60 & $\mathrm{Rp}$ & $13,612,900$ \\
11 & November & 28 & $\mathrm{Rp}$ & $19,406,050$ \\
12 & Desember & 30 & $\mathrm{Rp}$ & $8,619,600$ \\
\hline \multicolumn{2}{l}{ Total } & $\mathbf{7 1 5}$ & $\mathbf{R p}$ & $\mathbf{4 6 0 , 4 7 6 , 8 8 5}$ \\
\hline
\end{tabular}

Dari pengamatan yang dilakukan pada "Smartkids Distributor" Semarang ini kebijaksanaan potongan harga yang diberikan kurang mendapat perhatian.Kendala ini dapat mengakibatkan kurangnya minat konsumen dalam membelanjakan produk yang dipasarkan. Akibatnya target tahunan perusahaan masih sulit untuk dicapai, juga dikhawatirkan apabila konsumen berpindah ke perusahaan lain yang mungkin memiliki produk yang serupa dengan harga lebih murah. Oleh karena itu, harus dilakukan pembaharuan strategi promosi dalam bentuk potongan harga atau diskon kusus untuk konsumen yang total pembeliannya terbanyak dalam kurun waktu setahun.

Salah satu metode yang dapat membantu Smartkids Distributor dalam melakukan penilaian pelanggan terbaik serta penentuan diskon adalah Simple Additive Weighting(SAW) yang akan digunakan dalam menghitung pemilihan pelanggan terbaik karena dapat menentukan nilai bobot untuk setiap atribut, kemudian dilanjutkan dengan proses perangkingan yang akan menyeleksi alternatif terbaik dari sejumlah alternatif (Eniyati, 2011). Sedangkan Metode Technique for Order Preference by Similarity to Ideal Solution (TOPSIS) yang akan digunakan untuk menentukan diskonmerupakan konsep dimana alternatif terpilih yang terbaik tidak hanya memiliki jarak terpendek dari solusi ideal positif, namun juga memiliki jarak terpanjang dari solusi ideal negatif. Konsep ini banyak digunakan pada beberapa model MADM (Multi Atttribute Decision Making) untuk menyelesaikan masalah keputusan secara praktis (Sri Kusumadewi, 2006). 
Berdasarkan permasalahan yang ada, maka dibuatlah suatu program sistem informasi pendukung keputusan pelanggan tahunan dan pemberian diskon melalui rekap total pembelian konsumen dalam kurun waktu setahun. Untuk metode perhitungannya sendiri menggunakan Metode SAW sebagai pendukung keputusan pemilihan pelanggan terbaik dan TOPSIS sebagai pendukung keputusan pemberian diskon.Dimana keduanya memiliki konsep mencari penjumlahan terbobot dari rating kinerja pada setiap alternatif pada semua atribut sesuai dengan penerapan rumus masing-masing metode. Serta dengan proses akhir rancangan sistem tersebut berbasis web, sehingga mempermudah tim Smartkids dalam mengoperasikannya.

Penggunaan metode SAW dan TOPSIS memiliki masing-masing kriteria sebagai pembobot, yaitu : Tabel 2 : Kode kriteria pelanggan terbaik

\begin{tabular}{cl}
\hline Kode & Kriteria Pelanggan Terbaik \\
\hline C1 & Jumlah Pembelian \\
C2 & Total Retur \\
C3 & Lokasi \\
C4 & Persentase Kedatangan \\
C5 & Ketepatan Pembayaran \\
\hline
\end{tabular}

Tabel 3 : Kode Pemberian Diskon

\begin{tabular}{cl}
\hline Kode & Kriteria Pemberian Diskon \\
\hline $\mathrm{C} 1$ & Jumlah Buku yang dibeli \\
$\mathrm{C} 2$ & Jenis Buku yang dibeli \\
$\mathrm{C} 3$ & Retribusi Buku \\
\hline
\end{tabular}

\section{Perumusan Masalah}

1. Bagaimana merancang aplikasi untuk mempermudah proses dalam menentukan pelanggan terbaik menggunakan metode SAW?

2. Bagaimana merancang aplikasi untuk mempermudah proses dalam menentukan pemberian diskon menggunakan metode TOPSIS?

\section{Landasan Teori}

a. Simple Additive Weighting (SAW)

Metode SAW sering juga dikenal istilah metode penjumlahan terbobot. Konsep dasar metode SAW adalah mencari penjumlahan terbobot dari rating kinerja pada setiap alternatif pada semua atribut. Metode SAW membutuhkan proses normalisasi matriks keputusan (X) ke suatu skala yang dapat diperbandingkan dengan semua rating alternatif yang ada.

Langkah-langkah dari metode SAW adalah (Kusumadewi, 2006):

1) Menentukan kriteria-kriteria yang akan dijadikan acuan dalam pengambilan keputusan.

2) Menentukan rating kecocokan setiap alternative pada setiap kriteria.

3) Membuat matriks keputusan berdasarkan kriteria (C), kemudian melakukan normalisasi matriks berdasarkan persamaan yang disesuaikan dengan jenis atribut sehingga diperoleh matriks ternormalisasi R.

4) Hasil akhir diperoleh dari proses perangkingan yaitu penjumlahan dari perkalian matriks ternormalisasi $\mathrm{R}$ dengan vector bobot sehingga iperoleh nilai terbesar yang dipilih sebagai alternatif terbaik (A) sebagai solusi.

Formula untuk melakukan normalisasi tersebut adalah :

$$
\mathrm{r}_{\mathrm{ij}}=\left\{\begin{array}{l}
\frac{x i j}{M a x x i j} \\
\frac{M i n X i j}{x i j}
\end{array}\right.
$$

Dimana :

JURNAL ILMIAH ELEKTRONIKA DAN KOMPUTER Vol. 13, No. 1, Juli $2020: 18-33$ 


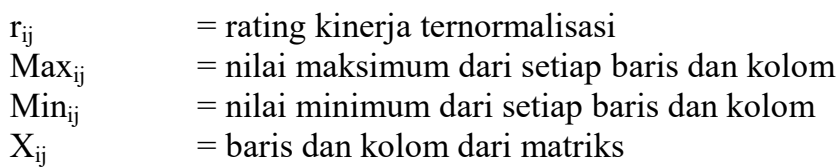

Dengan rij adalah rating kinerja ternormalisasi dari alternatif $\mathrm{Ai}$ pada atribut $\mathrm{Cj} ; \mathrm{i}=1,2, \ldots \mathrm{m}$ $\operatorname{dan} \mathrm{j}=1,2, \ldots, \mathrm{n}$.

Nilai preferensi untuk setiap alternatif (Vi) diberikan sebagai :

$\mathrm{Vi}=\sum_{j=1}^{n} W_{j} r_{i j}$

Dimana :

$\begin{array}{ll}\mathrm{V}_{\mathrm{i}} & =\text { Nilai akhir dari alternatif } \\ \mathrm{W}_{\mathrm{j}} & =\text { Bobot yang telah ditentukan } \\ \mathrm{r}_{\mathrm{ij}} & =\text { Normalisasi matriks }\end{array}$

Nilai Vi yang lebih besar mengindikasikan bahwa alternatif Ai lebih terpilih.

b. Topsis (Technique For Others Reference by Similarity to Ideal Solution)

TOPSIS (Technique For Others Reference by Similarity to Ideal Solution) adalah salah satu metode pengambilan keputusan multikriteria yang pertama kali diperkenalkan oleh Yoon dan Hwang (1981). Metode TOPSIS merupakan salah satu metode yang bisa membantu proses pengambilan keputusan yang optimal untuk menyelesaikan masalah keputusan secara praktis. Hal ini disebabkan karena konsepnya sederhana dan mudah dipahami, komputasinya efisien dan memiliki kemampuan untuk mengukur kinerja relatif dari alternatif-alternatif keputusan dalam bentuk matematis yang sederhana.

Secara umum, prosedur dari metode TOPSIS mengikuti langkah-langkah sebagai berikut :

a. Menentukan matriks keputusan yang ternormalisasi.

b. Menghitung matriks keputusan yang ternormalisasi terbobot.

c. Menghitung matriks solusi ideal positif dan matriks solusi ideal negatif.

d. Menghitung jarak antara nilai setiap alternatif dengan matriks solusi ideal positif dan matrik solusi ideal negatif.

e. Menghitung nilai preferensi untuk setiap alternatif.

Menghitung Matriks Ternomalisasi

Topsis membutuhkan rating kinerja tiap tenaga kerja pada setiap kriteria atau subkriteria yang ternormalisasi.

Matriks ternormalisasi terbentuk dari persamaan 1.

$$
\begin{aligned}
& (\text { yif })=\frac{x i f}{\sqrt{\sum_{\mathrm{i}}^{m}=\mathrm{i} x_{i f}^{T}}} \\
& \text { dimana } \mathrm{i}=1,2 \ldots . \mathrm{m} \text { dan } \mathrm{j}=1,2 \ldots . \mathrm{n}
\end{aligned}
$$

Menghitung matriks ternomalisasi

Persamaan 3 digunakan untuk menghitung matriks ternormalisasi terbobot, maka harus ditentukan terlebih dahulu nilai bobot yang merepresentasikan preferensi absolute dari pengambil keputusan. Nilai bobot preferensi menunjukkan tingkatkepentingan relatif setiap kriteria atau subkriteria pada persamaan 2 .

$$
\begin{aligned}
& W=\left\{w_{1}, w_{2}, w_{3}, \ldots, w_{n}\right\} \\
& \text { Persamaan } 3 \quad y_{i j}=w_{i} r_{i j} \\
& \text { dimana } i=1,2 \ldots . . m \text { dan } j=1,2 \ldots . n
\end{aligned}
$$




$$
\mathrm{Y}=\left[\begin{array}{cccc}
y^{11} & y 12 & \ldots . & y 1 n \\
y^{21} & y^{22} & \ldots . & y^{2 n} \\
& & & \\
& & & \\
y m 1 & y m 2 & \ldots . & y m n
\end{array}\right]
$$

Menghitung Matrik Solusi Ideal Positif dan Matriks Solusi Ideal Negatif

Solusi ideal positif dan solusi ideal negatif dapat ditentukan berdasarkan rating bobot ternormalisasi. Perlu diperhatikan syarat pada persamaan 4 dan 5 agar dapat menghitung nilai solusi ideal dengan terlebih dahulu menentukan apakah bersifat keuntungan (benefit) atau bersifat biaya (cost).

$$
\begin{aligned}
& \text { Persamaan } 4 \quad \mathrm{~A}^{+}=\left(\mathrm{y}_{1}^{+}, \mathrm{y}_{2}^{+}, \ldots, \mathrm{y}_{\mathrm{n}}^{+}\right) \\
& \text {Persamaan } 5 \quad \mathrm{~A}^{-}=\left(\mathrm{y}_{1}^{-}, \mathrm{y}_{2}^{-}, \ldots, \mathrm{y}_{\mathrm{n}}^{-}\right) \\
& \text {dimana: } \\
& \mathrm{Y}_{\mathrm{j}}^{+} \text {adalah: } \\
& \text { - } \max Y_{\mathrm{ij}} \text {, jika j adalah atribut keuntungan (benefit) } \\
& \text { - } \min Y_{\mathrm{ij}} \text {, jika } \mathrm{j} \text { adalah atribut biaya (cost) } \\
& Y_{j}^{-} \text {adalah: } \\
& \text { - } \min Y_{\mathrm{ij}} \text {, jika } \mathrm{j} \text { adalah atribut keuntungan (benefit) } \\
& \text { - } \max _{\mathrm{ij}} \text {, jika jadalah atribut biaya (cost) }
\end{aligned}
$$

Menentukan Jarak Antara Nilai Setiap Alternatif Dengan Matriks Solusi Ideal Positif dan Matriks Solusi Ideal Negative

Jarak alternatif $\left(\mathrm{D}_{\mathrm{i}}^{+}\right)$dengan solusi ideal positif dirumuskan pada persamaan 6 .

$$
D=\sqrt{\sum_{j}^{n}-j\left(y_{i}^{+}-y i j\right)^{2}}
$$

Jarak alternatif dengan solusi ideal negatif dirumuskan pada persamaan 7 .

$$
D i=\sqrt{\sum_{j=1}^{n}(y i f-y i)^{2}}
$$

Menghitung Niali Preferensi Untuk Setiap Alternatif

Nilai preferensi (Vi) untuk setiap alternatif dirumuskan dalam persamaan 8 .

$$
\mathrm{Vi}=\frac{D i}{D i+D i !}
$$

\section{Metodologi}

1. Metodologi penelitian adalah metode yang akan digunakan dalam melakukan sebuah penelitian. Dalam penelitian ini menggunakan metode RND, yang terdiri dari 6 tahapan, yaitu : Penelitian (Research and information collecting), Perencanaan (Planning), Pengembangan produk (Development preminary form of product), Uji coba tahap awal(Preliminary field testing), Revisi produk(Main product revision), Uji coba lapangan (Main field testing).

\subsection{Desain Penelitian}

Sistem yang kompleks bisa dipahami dengan memecahkannya menjadi elemen-elemen yang lebih kecil dan mudah dipahami.

1. Decomposisi

JURNAL ILMIAH ELEKTRONIKA DAN KOMPUTER Vol. 13, No. 1, Juli $2020: 18-33$ 


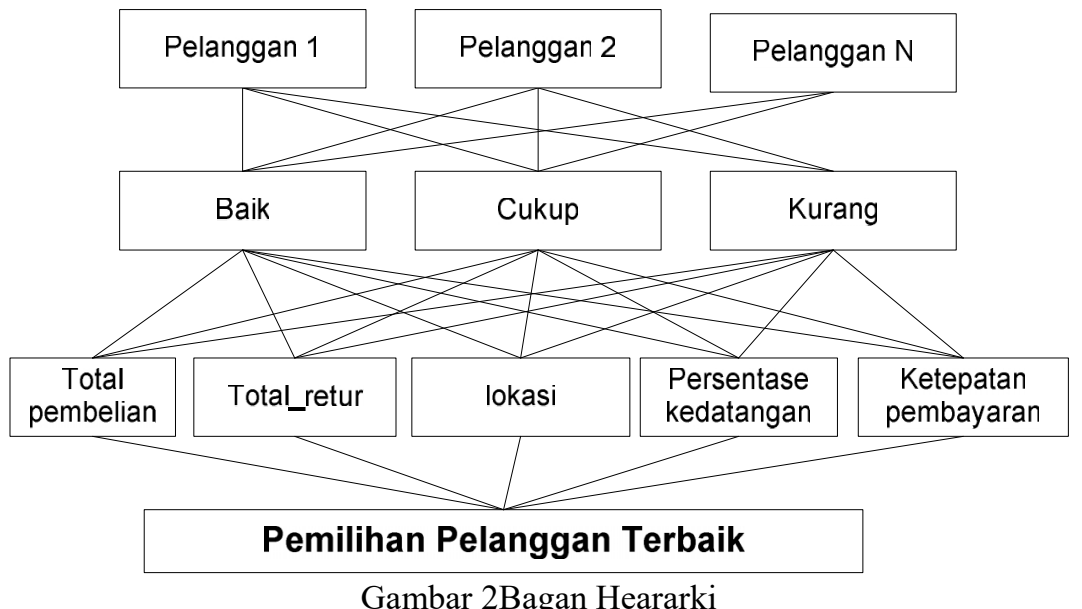

a. Total Pembelian

Total Pembelian merupakan jumlah pembelian tiap pelanggan dalam kurun waktu 1 (satu) tahun.

b. Total Retur

Total Retur merupakan jumlah pengembalian barang yang telah dibeli oleh tiap pelanggan daalam kurun waktu 1 (satu) tahun.

c. Lokasi

Lokasi merupakan jarak antara tempat tinggal pelanggan dengan toko Smartkids.

d. Persentase Kedatangan

Persentase Kedatangan merupakan seberapa sering pelanggan tersebut datang dan melakukan pembelian di toko.

e. Ketepatan Pembayaran

Ketepatan Pembayaran merupakan jangka waktu pembayaran seorang pelanggan setiap bertransaksi (piutang).

2. Data Flow Diagram (DFD)

Data Flow Diagram (DFD) adalah representasi grafik dari sebuah sistem. DFD menggambarkan komponen-komponen sebuah sistem, aliran-aliran data di mana komponenkomponen tersebut, dan asal, tujuan, dan penyimpanan dari data tersebut. Dengan adanya DFD, arah perancangan akan menjadi lebih jelas dengan langkah-langkah yang terstruktur. 


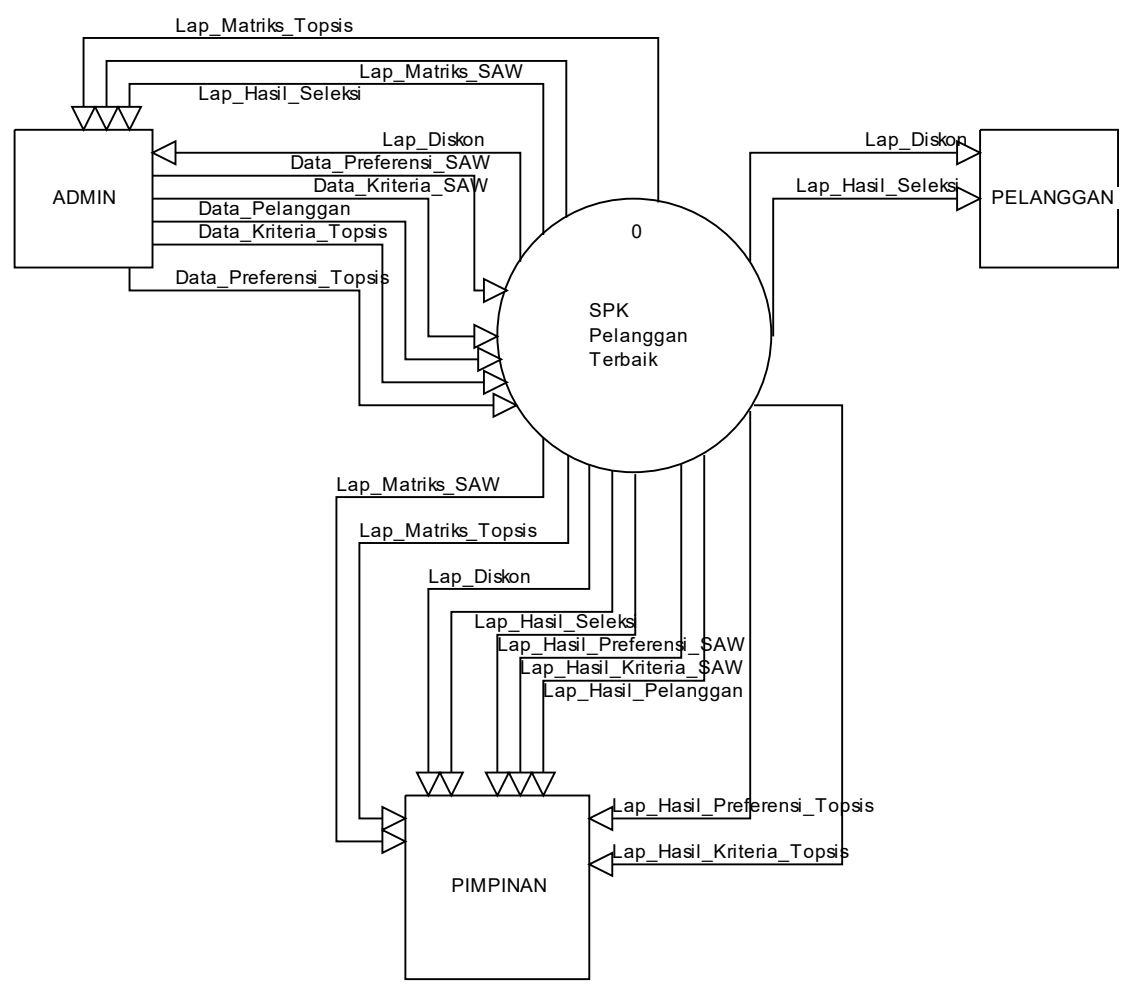

Gambar 3 : Diagram Konteks

Keterangan

a. Admin memasukkan data pelanggan, data preferensi Topsis, data preferensi SAW, data kriteria Topsis, dan data kriteria SAW ke dalam sistem.

b. Laporan hasil data-data yang dimasukkan ke sistem kemudian diserahkan ke Pimpinan berupa laporan matriks SAW, laporan matriks Topsis, laporan hasil seleksi, laporan hasil preferensi Topsis, laporan hasil preferensi SAW, laporan hasil kriteria Topsis, laporan hasil kriteria SAW, laporan hasil pelanggan, dan laporan diskon.

c. Pelanggan menerima laporan diskon dan laporan hasil seleksi berupa informasi dari admin. 
3. Data Flow of Diagram Level 0

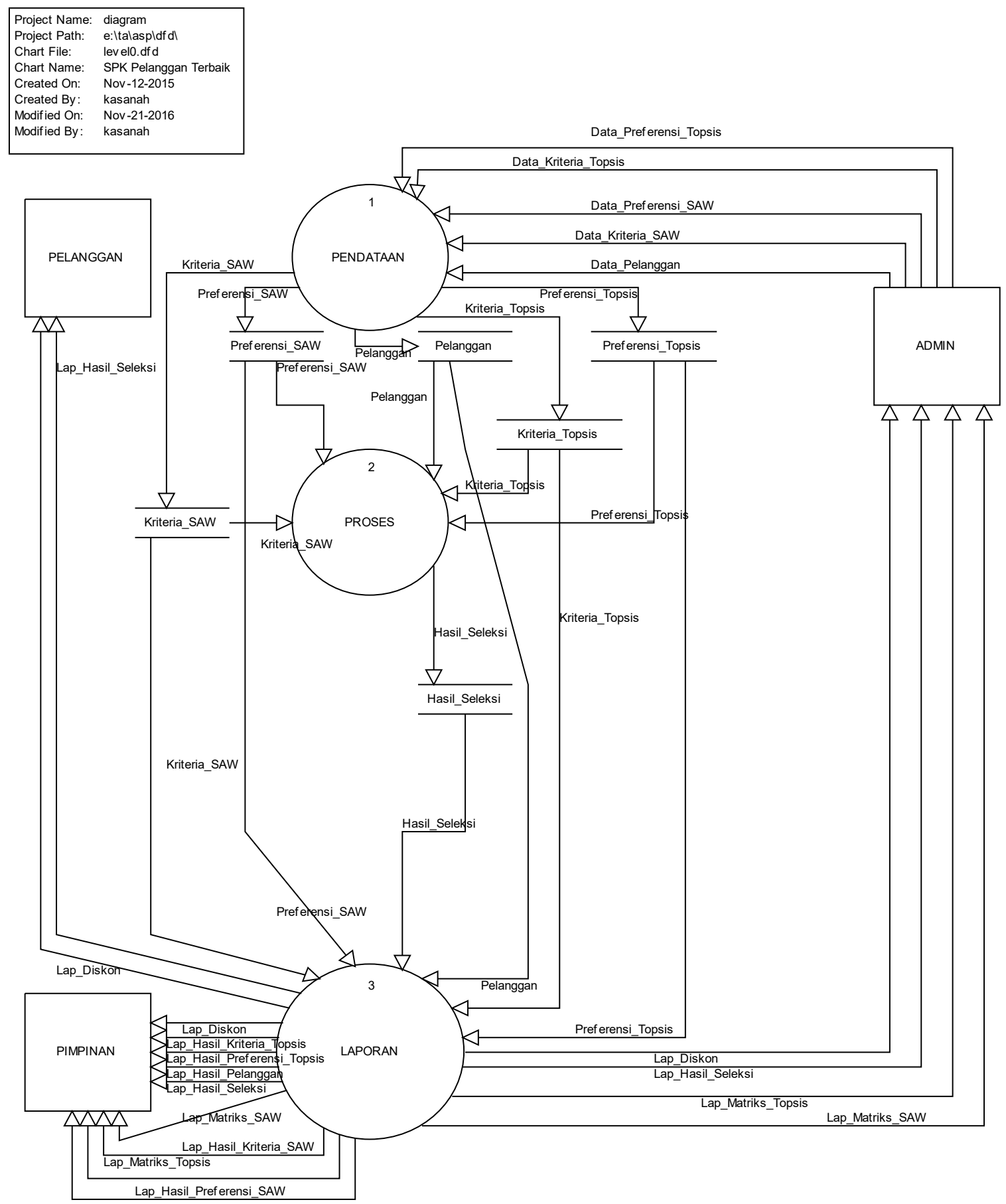

Gambar 4Data Flow Diagram Level 0

Keterangan :

a. Dari admin masuk ke sistem pendataan berupa data Pelanggan, data preferensi SAW, data preferensi Topsis, data kriteria SAW, data kriteria Topsis. Sedangkan sistem pendataan menyimpan data ke masing-masing database pelanggan, database preferensi SAW, database preferensi Topsis, database kriteria SAW dan database kriteria Topsis.

b. Dari database sistem pendataan akan masuk kedalam sistem proses yang mana sistem proses akan memproses data masukan dan menghasilkan hasil seleksi berupa database. 
c. Dari sistem pendataan dan sistem proses yang berupa database masuk ke dalam sistem laporan, sehingga dari sistem laporan menghasilkan beberapa laporan yang akan diserahkan oleh admin, pimpinan, dan pelanggan.

d. Dari sistem laporan, pimpinan akan menerima laporan matriks Topsis, laporan matriks SAW, laporan hasil seleksi, laporan hail pelanggan, laporan hasil preferensi SAW, laporan hasil preferensi Topsis, laporan kriteria SAW, laporan kriteria Topsis dan laporan diskon

e. Sistem laporan juga akan mengeluarkan Laporan matriks SAW, laporan matriks Topsis, laporan hasil seleksi, dan laporan diskon. Beberapa laporan tersebut diterima oleh admin. Sedangkan pelanggan hanya menerima laporan seleksi dan laporan diskon.

4. Data Flow of Diagram level 1 Pendataan

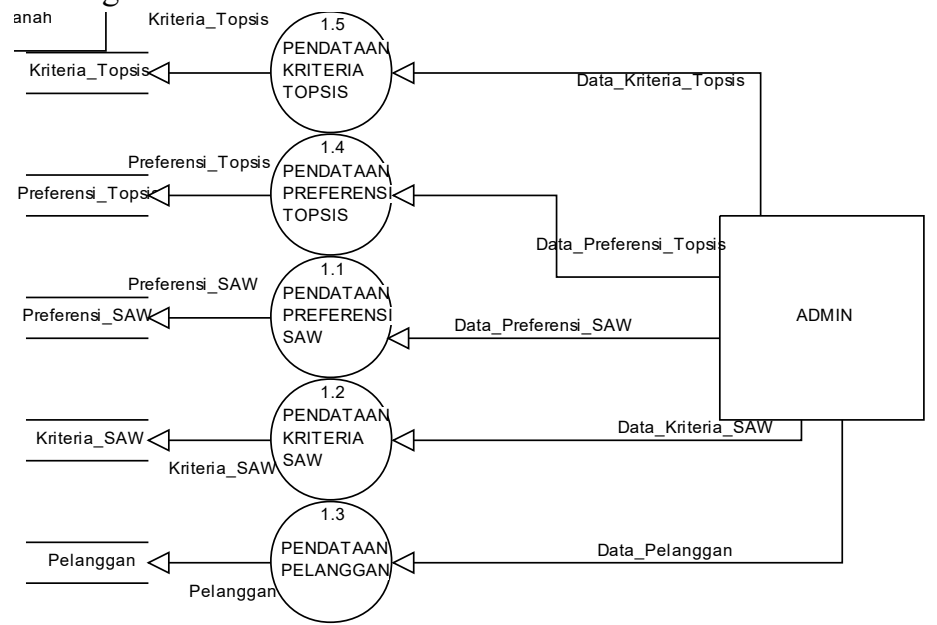

Gambar 5 : Data Flow Diagram Level 0

Keterangan :

a. Dari admin masuk ke sistem pendataan berupa data kriteria Topsis, kemudian tersimpan berupa database kriteria Topsis.

b. Dari admin masuk ke sistem pendataan berupa data preferensi Topsis, kemudian tersimpan berupa database preferensi Topsis.

c. Dari admin masuk ke sistem pendataan berupa data Preferensi SAW, kemudian tersimpan berupa database Preferensi SAW.

d. Dari admin masuk ke sistem pendataan berupa data kriteria SAW, kemudian tersimpan berupa database kriteria SAW.

e. ari admin masuk ke sistem pendataan berupa data Pelanggan, kemudian tersimpan berupa database Pelanggan.

5. Data Flow of Diagram level 1 Proses

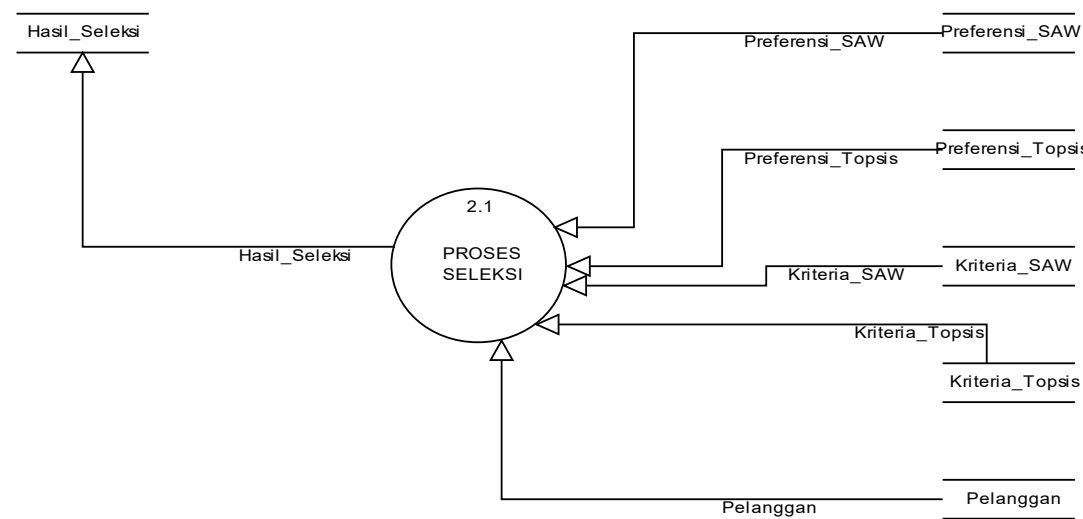

Gambar 6 : Data Flow Diagram Level 0

JURNAL ILMIAH ELEKTRONIKA DAN KOMPUTER Vol. 13, No. 1, Juli $2020: 18-33$ 
Keterangan :

Dari data Pelanggan, data Kriteria SAW, data Kriteria Topsis, data Preferensi SAW, dan data Preferensi Topsis masuk kedalam sistem Proses Seleksi akan menghasilkan berupa data Hasil Seleksi.

6. Data Flow of Diagram level 1 Laporan

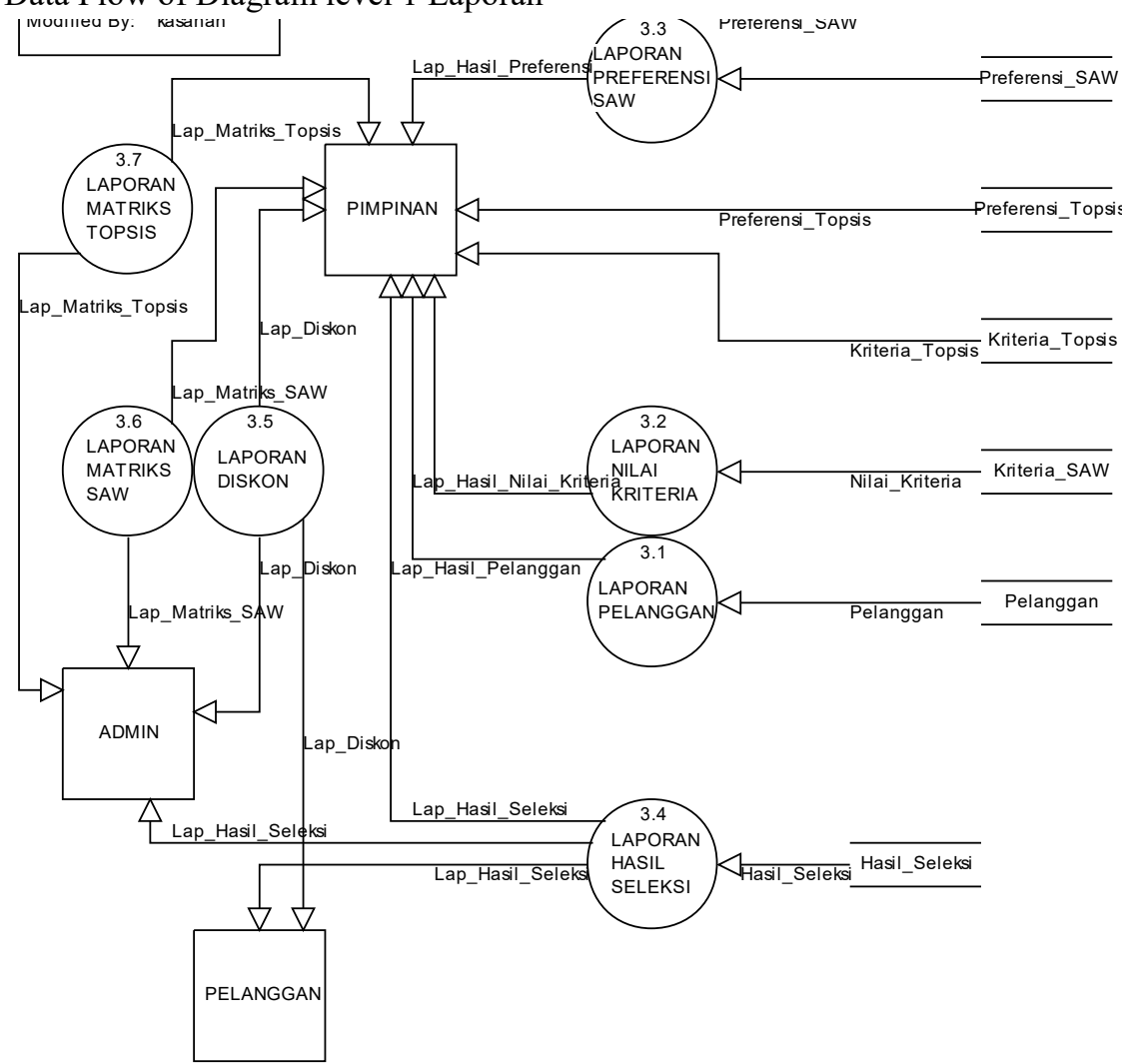

Gambar 7 : Data Flow Diagram Level 0

Keterangan :

Dari data seleksi, pelanggan, kriteria SAW, kriteria Topsis, preferensi SAW, dan preferensi Topsis akan masuk ke sistem masing-masing laporan dan akan dikirim ke Pimpinan, admin dan pelanggan. 
7. $\quad$ ERD (Entity Relationship Diagram)

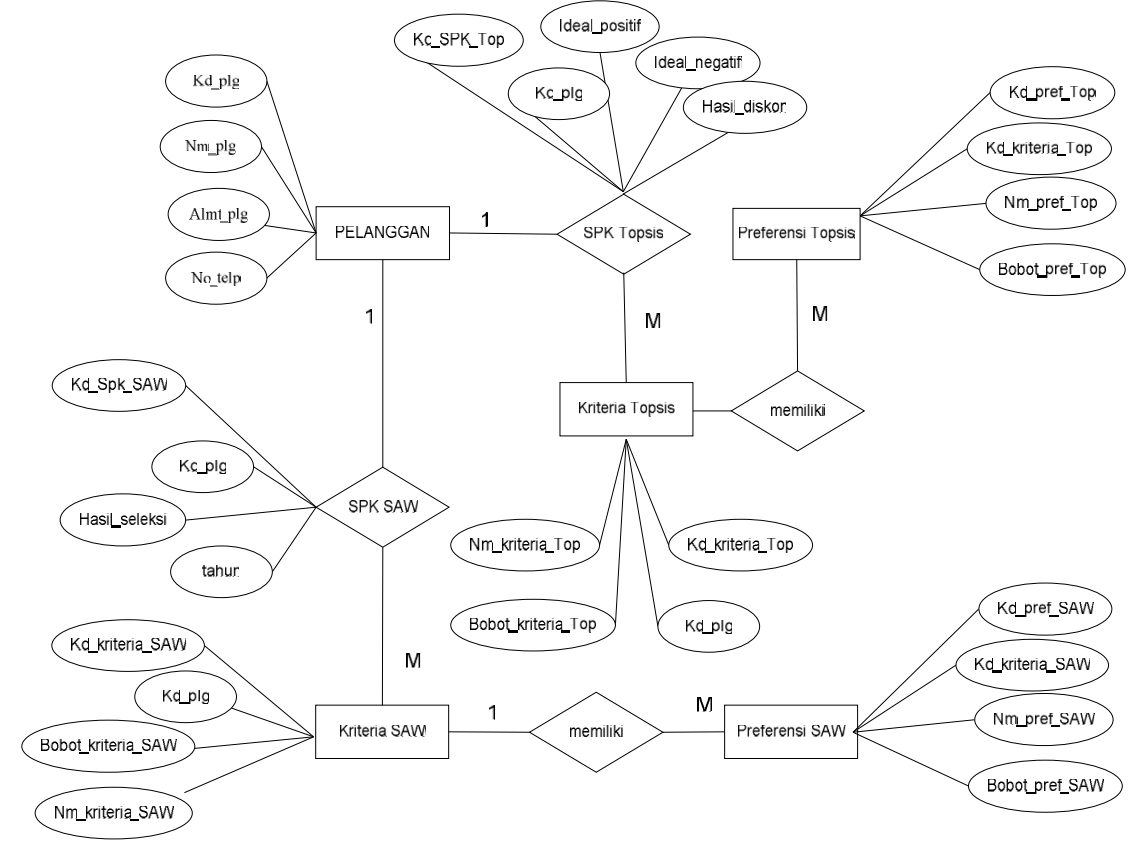

Gambar 8 : ERD

\section{Hasil dan Pembahasan}

a. Form Pelanggan

Form pelanggan merupakan form yang digunakan untuk mendata pelanggan, pada from pelanggan juga terdapat berapa kriteria yang digunakan sebagai perhitungan metode SAW. Kriteria meliputi jumlah pembelian, total retur, laba, presentasi kedatangan, ketepatan pembayaran.

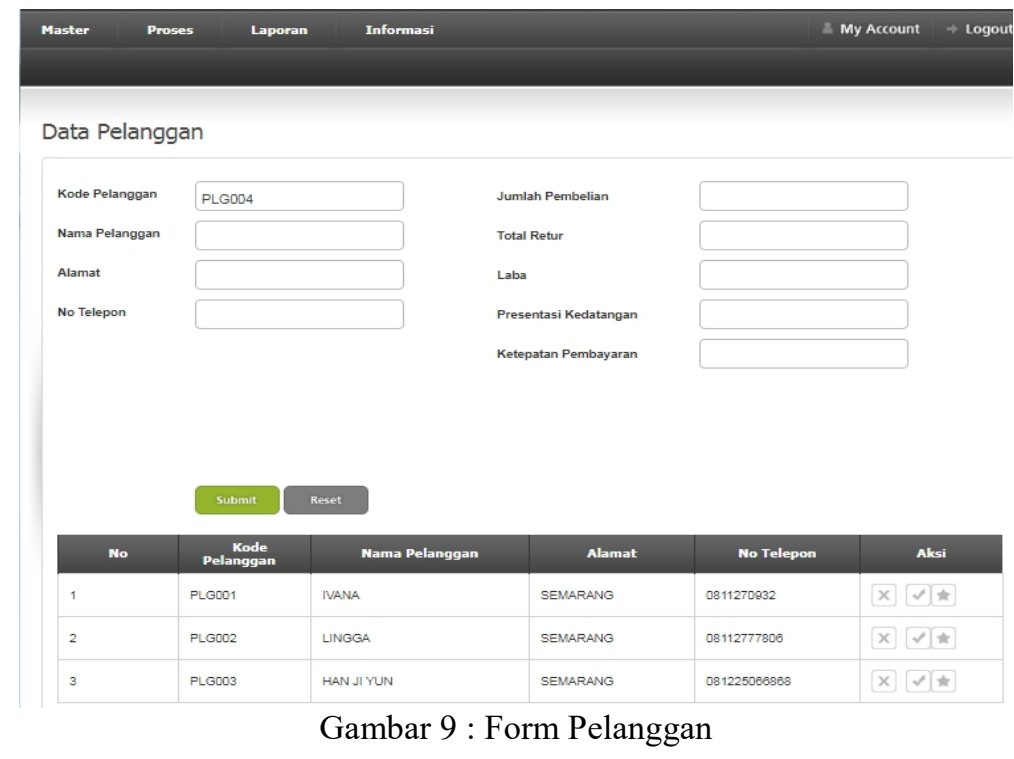

JURNAL ILMIAH ELEKTRONIKA DAN KOMPUTER Vol. 13, No. 1, Juli $2020: 18-33$ 


\section{b. Form Preferensi SAW}

Form preferensi SAW adalah form yang digunakan untuk memberikan penilaan dari bobot kepentingan antara tiap-tiap kriteria. Diantaranya adalah jumlah pembelian, total retur, laba, presensi kehadiran, kecepatan pembayaran.

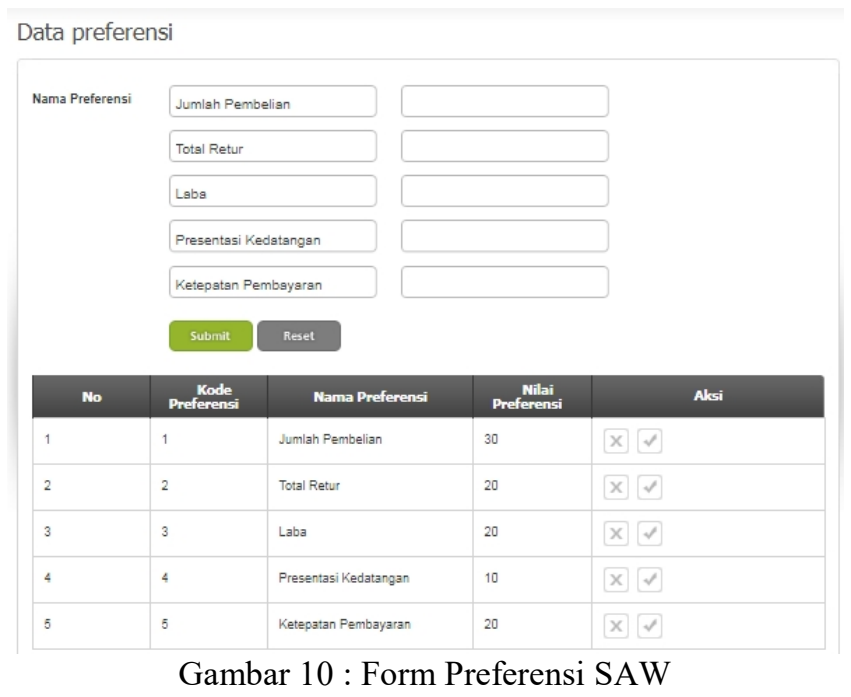

c. Form Matriks SAW

Form matrik SAW merupakan form yang digunakan untuk melakukan perhitungan menggunakan metode algoritma SAW.

1) Pada tabel berwarna hijau terdapat nilai pada pelanggan PLG001, dimana jumlah pembelian nilai 4 , total retur 5, laba 5, presentase kedatangan 4, dan ketepatan pembayaran 4.

2) Pada tabel berwarna abu-abu merupakan nilai bobot antar kriteria. Dimana jumlah pembelian nilai 30 , total retur 20 , laba 10 , presentase kedatangan 10 , dan ketepatan pembayaran 20.

3) Pada tabel ke 3 warna coklat, merupakan nilai dari perhitungan nilai bobot kriteria dibagi dengan nilai tertinggi dari bobot kriteria.

4) Pada tabel ke 4 warna coklat, merupakan nilai perhitungan bobot preferensi * nilai bobot pada kolom 3.

contoh PLG003=30*0,75 = 22,5

5) Pada tabel ke terdapat kolom peringkat, merupakan nilai dari penjumlahan dari semua nilai kriteria pada tiap-tiap alternatif (pelanggan).

Contoh: PLG001 memiliki nilai $=22.5+20+12+7.5+20=82$ 
Data Normalisasi Matriks

\begin{tabular}{|l|l|l|l|l|c|c|}
\hline No & Kode Pelanggan & Jumlah Pembelian & Total Retur & Laba & $\begin{array}{c}\text { Presentase } \\
\text { Kedatangan }\end{array}$ & $\begin{array}{c}\text { Kategatan } \\
\text { Pembayaran }\end{array}$ \\
\hline 1. & PLG001 & 4 & 5 & 5 & 4 & 4 \\
\hline 2. & PLG002 & 4 & 5 & 5 & 4 & 3 \\
\hline 3. & PLG003 & 3 & 5 & 3 & 3 & 3 \\
\hline & Nilai Tertinggi & 4 & 5 & 5 & 4 & 3 \\
\hline
\end{tabular}

\begin{tabular}{|c|c|c|c|c|c|}
\hline Bobot Preferensi & Jumlah Pembelian & Total Retur & Laba & $\begin{array}{c}\text { Presentase } \\
\text { Kedatangan }\end{array}$ & $\begin{array}{c}\text { Ketepatan } \\
\text { Pembayaran }\end{array}$ \\
\hline & 30 & 20 & 20 & 10 & 20 \\
\hline
\end{tabular}

\begin{tabular}{|l|l|c|c|c|c|c|}
\hline No & Kode Pelanggan & Jumlah Pembelian & Total Retur & Laba & $\begin{array}{c}\text { Presentase } \\
\text { Kedatangan }\end{array}$ & $\begin{array}{c}\text { Ketepatan } \\
\text { Pembayaran }\end{array}$ \\
\hline 1. & PLG001 & 1 & 1 & 1 & 1 & 1.333333333333 \\
\hline 2. & PLG002 & 1 & 1 & 1 & 1 & 1 \\
\hline 3. & PLG003 & 0.75 & 1 & 0.6 & 0.75 & 1 \\
\hline
\end{tabular}

\begin{tabular}{|l|l|c|c|c|c|c|c|}
\hline No & \multicolumn{1}{|c|}{ Kode Pelanggan } & $\begin{array}{c}\text { Jumlah } \\
\text { Pembelian }\end{array}$ & Total Retur & Laba & $\begin{array}{c}\text { Presentasi } \\
\text { Kedatangan }\end{array}$ & $\begin{array}{c}\text { Ketepatan } \\
\text { Pembayaran }\end{array}$ & Peringkat \\
\hline$\square$ & PLG001 & 30 & 20 & 20 & 10 & 26.6868686887 & 106.686868687 \\
\hline$\square$ & PLG002 & 30 & 20 & 20 & 10 & 20 & 100 \\
\hline$\square$ & PLG003 & 22.5 & 20 & 12 & 7.5 & 20 & 82 \\
\hline
\end{tabular}

\section{d. Form Kriteria TOPSIS}

Form kriteria TOPSIS merupakan form yang digunakan untuk memasukkan nilai kriteria pelanggan dari perhitungan algoritma TOPSIS, yang memiliki kriteria jumlah buku, jenis buku, dan retribusi buku.

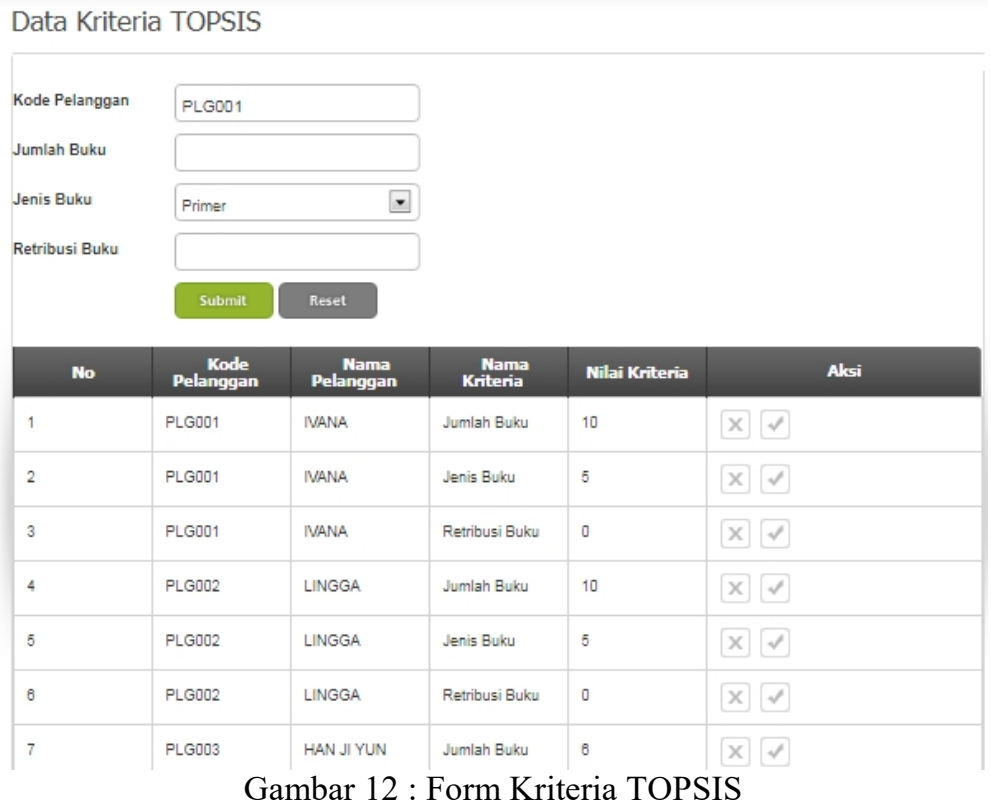

JURNAL ILMIAH ELEKTRONIKA DAN KOMPUTER Vol. 13, No. 1, Juli $2020: 18-33$ 
31

Keterangan gambar 12 :

Pada daftar data nilai kriteria topsis terdapat data sebagai berikut :

Nana memiliki nilai jumlah buku 10 , jenis buku 5 , retribusi buku 0 , sedangkan lingga memiliki data nilai jumlah buku 10 , jenis buku 5 , retribusi buku 0 , sedangkan Lia memiliki data nilai jumlah buku 6, jenis buku 5, retribusi buku 11000

e. Form Preferensi Topsis

Form preferensi TOPSIS adalah form yang digunakan untuk memberikan penilaan dari bobot kepentingan antara tiap-tiap kriteria. Diantaranya adalah jumlah buku, jenis buku, retribusi buku.

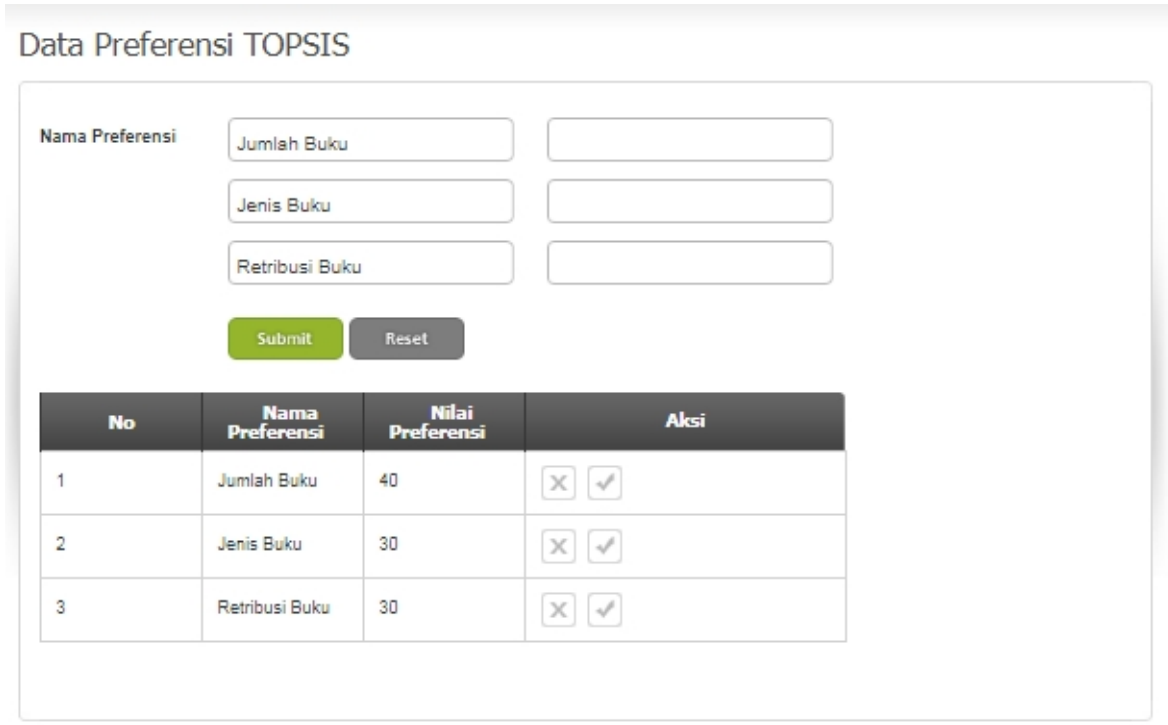

Gambar 13 : Form Preferensi TOPSIS

Keterangan gambar 13 :

Nilai bobot preferensi dari kriteria jumlah buku 40, jenis buku 30, dan retribusi buku 30. Dari data tersebut untuk kriteria jumlah buku memiliki nilai paling tinggi, maka dinyatakan sebagai bobot paling penting diantara kriteria yang lain. 
f. Form Matriks Topsis

Form matrik TOPSIS merupakan form yang digunakan untuk melakukan perhitungan algoritma dari metode TOPSIS.

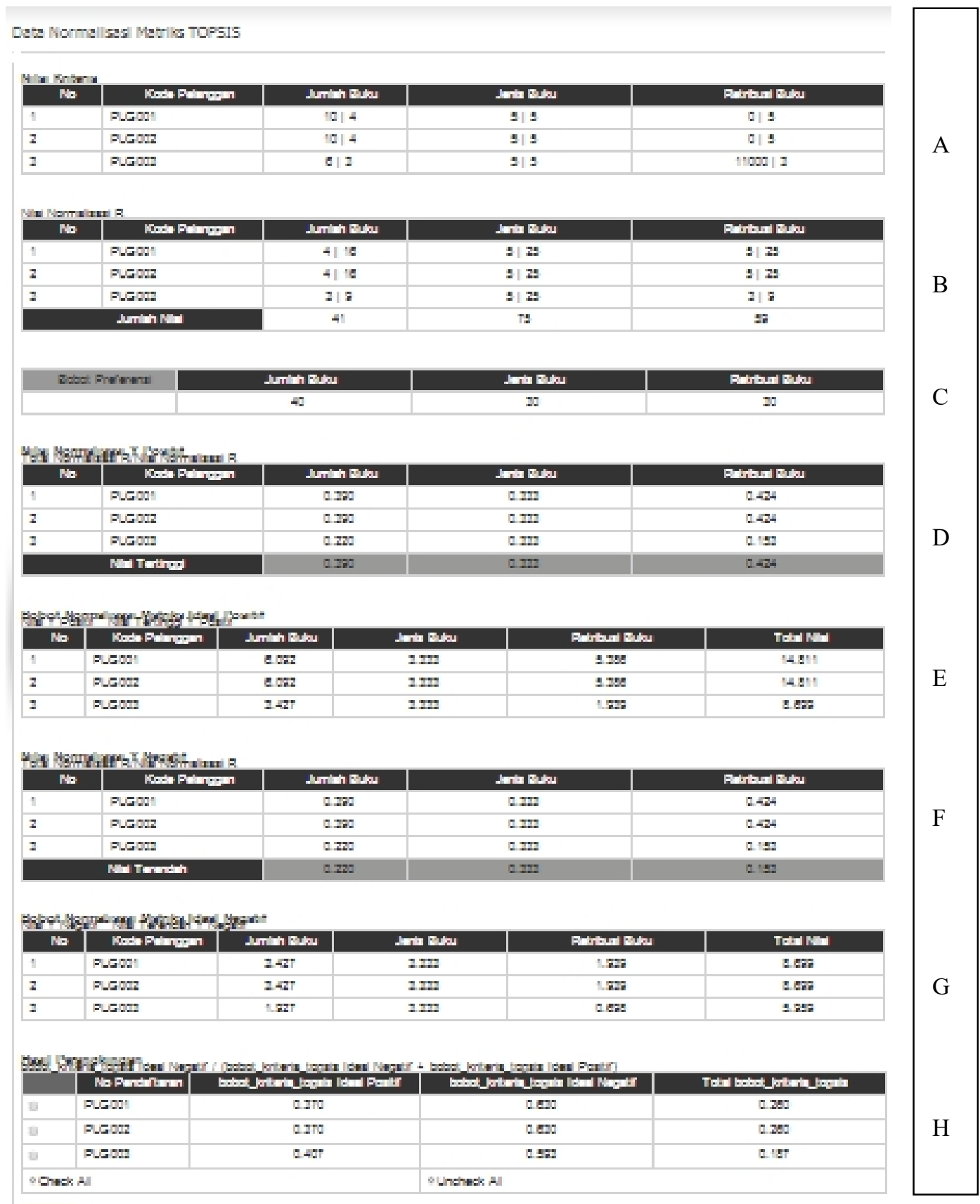

Gambar 14 : Form Preferensi TOPSIS

Keterangan Gambar 14 :
a. Kolom A
Pada kolom A menampilkan data nilai kriteria dari pelanggan PLG001, PLG002, PLG003
b. Kolom B

JURNAL ILMIAH ELEKTRONIKA DAN KOMPUTER Vol. 13, No. 1, Juli $2020: 18-33$ 
Pada kolom B menampilkan data Normalisasi R, yaitu menghitung nilai bobot kriteriadan menjumlahkan dari nilai bobot kriteria.

c. Kolom C

Pada kolom C merupakan nilai dari bobot preferensi dari antar tiap kriteria

d. Kolom D

Pada kolom D merupakan nilai normalisasi ideal Y Positif dengan persamaan rumus 6

e. Kolom E

Pada kolom E merupakan hasil nilai normalisasi ideal Y Positif dengan persamaan rumus 6

f. Kolom F

Pada kolom $\mathrm{F}$ merupakan nilai normalisasi ideal $\mathrm{Z}$ Negatif dengan persamaan rumus 6

g. Kolom G

Pada kolom $\mathrm{G}$ merupakan hasil nilai normalisasi ideal $\mathrm{Z}$ negatif dengan persamaan rumus 6

h. Kolom $\mathrm{H}$

Pada kolom H merupakan nilai Separation measure yaitu mengukur jarak antara suatu alternatif terhadap nilai ideal positif dan nilai ideal negatif.

\section{Kesimpulan} berikut:

Berdasarkan pembahasan dan evaluasi dari bab terdahulu, maka dapat ditarik kesimpulan sebagai

a. Dengan menggunakan bahasa pemrograman PHP dapat digunakan untuk membantu pihak perusahaan untuk memilih pelanggan terbaik dan penentuan diskon secara valid.

b. Aplikasi yang telah dibuat dapat digunakan sebagai alat bantu bagi pengambil keputusan dengan tetap berbasis pada sistem pendukung keputusan lebih efektif dalam pemilihan pelanggan terbaik dan penentuan diskon menggunakan metode SAW (Simple Additive Weighting) dan Topsis (Technique for Order Preference by Similarity to Ideal Solution).

\section{Daftar Pustaka}

Agustina Silvi, Rachmadi Aditya , S.ST,. M.TI., Wicaksono Satrio Agung S.Kom., M.Kom., 2012; "Sistem Pendukung Keputusan Penentuan Prioritas Pelanggan Dealer Suzuki Soekarno Hatta Malang Menggunakan Metode AHP Dan SAW”, Program Studi Ilmu Komputer, Jurusan Ilmu Komputer, Fakultas Program Teknologi Informasi dan Ilmu Komputer.

Betha Sidik, 2012; “ Pemrograman Web dengan PHP”, Bandung : Informasi Bandung.

Kusrini, 2007; “Konsep dan Aplikasi Sistem Pendukung Keputusan”, Yogyakarta : Andi Offset

Sholikhah Fatikhatus, Satyareni Diema Hernyka, Anugerah Chandra Sukma, 2016; "Perancangan Sistem Pendukung Keputusan Pemilihan Pelanggan Terbaik Menggunakan Metode SAW Pada Bravo Supermarket Jombang”, Universitas Pesantren Tinggi Darul ‘Ulum (Unipdu) Jombang.

Sugiyono, 2014; “Metode Penelitian Kuantitatif Kualitatif dan R\&D”, Bandung : Alfabeta Bandung.

Sunyoto Danang, 2014; "Sistem Informasi Manajemen Perspektif Organisasi”, Yogyakarta: CAPS.

Sri Kusumadewi, Sri Hartati, Agus Harjoko. (2006)" Fuzzy Multi Atribut Decision Making (Fuzzy MADM)" Graha Ilmu: Yogyakarta.

Triwibowo Soedjas, 2014; “Layanan Untuk Pelanggan”, Yogyakarta: Media Pressindo. 